Research

Elsevier Editorial System(tm) for Algal

Manuscript Draft

Manuscript Number: ALGAL-D-15-00210R2

Title: New mechanistic model to simulate microalgae growth

Article Type: Full Length Article

Section/Category: Algal Biotechnology

Keywords: Photobioreactors, HRAPS, Photolimitation, Oxygen inhibition, Irradiance, Photosynthetic factories.

Corresponding Author: Prof. Joan Garcia, PhD

Corresponding Author's Institution: Technical University of Catalonia

First Author: Alessandro Solimeno

Order of Authors: Alessandro Solimeno; Roger Samsó; Enrica Uggetti; Bruno Sialve; Jean-Philippe Steyer; Adrián Gabarró; Joan Garcia, PhD

Abstract: The prospect of treating wastewater and at the same time producing microalgae biomass is receiving increasing attention. Mechanistic models for microalgae growth in wastewater are currently being developed for new systems design as well as to improve the understanding of the involved biokinetic processes. However, mathematical models able to describe the complexity of microalgal cultures are still not a common practice. The aim of the present study is to present and calibrate a new mechanistic model built in COMSOL MultiphysicsTM platform for the description of microalgae growth. Carbon-limited algal growth, transfer of gases to the atmosphere; and photorespiration, photosynthesis kinetics and photoinhibition are included. The model considers the growth of microalgae as a function of light intensity and temperature, as well as availability of nitrogen and other nutrients. The model was calibrated using experimental data from a case study based on the cultivation of microalgae species in synthetic culture medium. The model was able to reproduce experimental data. Simulations results show the potential of the model to predict microalgae growth and production, nutrient uptake, and the influence of temperature, light intensity and pH on biokinetic processes of microalgae. 


\title{
New mechanistic model to simulate microalgae growth
}

\author{
Alessandro Solimeno*, Roger Samsó*, Enrica Uggetti*, Bruno Sialve**, Jean-Philippe \\ Steyer**, Adrián Gabarró* and Joan García* \\ *GEMMA - Group of Environmental Engineering and Microbiology, Department of Hydraulic, Maritime and Environmental
Engineering, UniversitatPolitècnica de Catalunya-BarcelonaTech, c/Jordi Girona, 1-3, Building D1, E-08034, Barcelona, Spain.
**INRA, UR0050, Laboratoire de Biotechnlogie de l'Environnement, Avenue des Etangs, Narbonne, F-11100, France. \\ Corresponding author. Tel,: +34 93401 6464; fax 34934017357. \\ E-mail address: joan.garcia@upc.edu (J. García).
}

\begin{abstract}
The prospect of treating wastewater and at the same time producing microalgae biomass is receiving increasing attention. Mechanistic models for microalgae growth in wastewater are currently being developed for new systems design as well as to improve the understanding of the involved biokinetic processes. However, mathematical models able to describe the complexity of microalgal cultures are still not a common practice. The aim of the present study is to present and calibrate a new mechanistic modelbuilt in COMSOL Multiphysics ${ }^{\mathrm{TM}}$ platformfor the description of microalgae growth. Carbon-limited algal growth, transfer of gases to the atmosphere; and photorespiration,photosynthesis kinetics and photoinhibitionare included. The model considersthe growth of microalgae as a function of light intensity and temperature, as well as availability of nitrogen and other nutrients. The model was calibrated using experimental data froma case study based on the cultivation of microalgae species in syntheticculture medium. The model was able to reproduce experimental data. Simulations results show the potential of the model to predict microalgae growth and production, nutrient uptake, and the influence of temperature, light intensity and $\mathrm{pH}$ on biokinetic processes of microalgae.
\end{abstract}

Keywords: Photobioreactors, $\mathrm{HRAP}_{\mathrm{S}}$, Photolimitation, Oxygen inhibition, Irradiance, Photosynthetic factories.

\section{Introduction}

Microalgae are nowadays used to produce a variety of compounds of interest for different industrial sectors such as aquaculture and animal feed, human nutrition, cosmetics and nutraceutics as well as pharmaceutics (Spolaore et al., 2006;Acién et al., 2013). In addition, these microorganisms have a great potential for $\mathrm{CO}_{2}$ capture and biofuels production such as biodiesel(Craggs et al., 2011).In fact, in recent yearsa tremendous effort has been madein numerous research centres to obtain biodiesel from microalgae; however the industrial production of biodiesel is still far from becominga consolidated technology (Chisti, 2007; Brennan and Owende, 2010).

Another biotechnological application of microalgae is their use for wastewater treatment. Since the late 1950s, the growth of mixed consortia of microalgae and bacteria has been promoted in high rate algal ponds (HRAP) with that aim.In these treatment systems microalgae provide the required oxygen for the degradation of certain wastewater constituents byaerobic bacteria. Though the interest in this technologydecreased over the years, in the current context of energy crisisit is 
skyrocketing again due to its dual benefit:treating wastewater and producing algal biomass that can be valorised in the form of biofuels or bioproducts (Park et al., 2011).

All these microalgal biotechnology applications require tools that allow us toforecast biomass production in order to ensure feasibility for valorisation of microalgae as products or biofuels (Béchet et al., 2013). At the same time productionforecasting is challenging because microalgae growth depends on many parameters such as solar radiation, nutrients availability (e.g.carbon and nitrogen) as well ason certain inhibitory conditions(e.g. excess of oxygen in the algal culture).

Mathematical models offer a great opportunity to study the simultaneous effect of different factors affecting algal growth and allow forecastingalgal production.Research on microalgae growth kinetics modeling started with the pioneering work by Droop $(1968,1974)$. Since then a number of researchers have developed models based on single factors such as light intensity (Huisman, 1999), temperature (Franz et al., 2012), nitrogen (Bernard et al., 2009) and photosynthesis and photoinhibition effects ( $\mathrm{Wu}$ and Merchuk, 2001). In fact, there is a vast array of models thatpredict biomass production as a function of light intensity (Yuan et al., 2014). This results from the fact that light cannot be easily controlled at full-scale microalgae cultures, in contrast to other factors which are maintained at optimal conditions to avoid limiting or inhibitory effects (e.g. $\mathrm{pH}$, nutrients and mixing conditions). Recently,models of increasing complexity with two or more factors have been developed (Packer et al., 2011;Bonachela et al., 2011). As an example, in the model by Bernard (2011) light intensity and nitrogen are the limiting factors for microalgae growth. Most of these previous models usefewparameters to describe the inherent complexity of algal cultures, especially so in the particular case of microalgae grown in wastewaters, where carbon and nitrogen limitations can be significant. Therefore the main objective of the thispaper is to presenta new mechanistic model that includes crucial physical and biokinetic processes for the description of microalgae growth in different types of cultures, and most particularly in wastewater.

The main source of inspiration for building the presented model was the River Water Quality Model 1 (RWQM1) of the International Water Association (Reichert et al., 2011). RWQM1 was selected because it belongs to a family of widely accepted models (e.g. the Activated Sludge Models (ASM)) which share the same presentation, notation and structure for compounds, processes, and kinetic constants (Henze et al., 2000; Sah et al., 2011). Moreover, RWQM1 is the unique in the IWA family models because it considers microalgae activity.

The model was implementedin the COMSOL Multiphysics ${ }^{\mathrm{TM}}$ software, which solves differential equations using the finite elements method (FEM). For calibration we used experimental data obtained from a culture medium simulatingtreated urban wastewater (i.e. secondary effluent). This model will provide new insight into the functioning of microalgae cultures, and will help to explore the simultaneous effects of factors affecting microalgae growth.It is also a part of a more ambitious project throughwhich we intendto developacomplete model to simulatemixed cultures of microalgae and bacteria treating wastewater (like HRAP or photobioreactors). 


\section{Model description}

\subsection{Conceptual model}

The conceptual understanding that we have of the modelled system is shown in Figure 1. This figure shows that microalgae grow with light, consume substrates (i.e. carbon and nitrogen) and release oxygen. Note that other nutrients (e.g. phosphorus) and micronutrients are not considered to be limiting factors because are usually highly available in wastewater (which is the type of culture that mainly addresses the present model)(Larsdotter, 2006)As a result of microalgal activity,hydroxide ions concentration and $\mathrm{pH}$ increase. Increasing $\mathrm{pHs}$ displace the equilibrium of the carbon species towards the formation of carbonates. In darkness, endogenous respiration and inactivation of microalgae releasecarbon dioxide, the concentration of hydrogen ions increase and $\mathrm{pH}$ decreases. By decreasing $\mathrm{pH}$ the carbon equilibrium shifts and carbonateturns into bicarbonate, which can be used as substrate again in the presence of light.

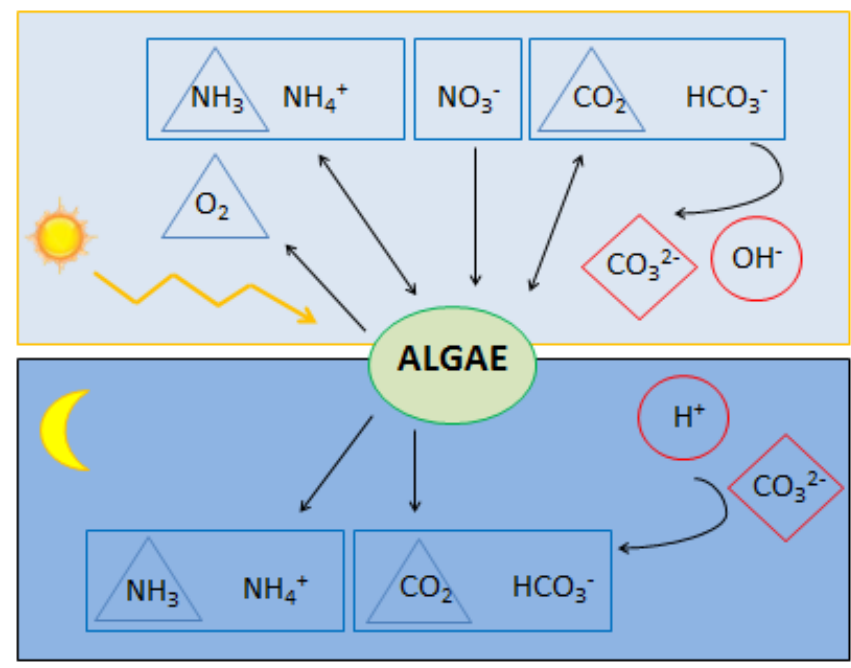

Figure 1.General schematicrepresentationof the conceptual model.Microalgae (green ellipse), substrates (rectangles),gaseous species (triangles) and species depending on algal activitywhich are neither substratesnor gases (diamonds and circles).Other nutrients (e.g. phosphorus) and micronutrients are not limiting factors.

\subsection{Model components}

The model follows the most commonly used nomenclature in the IWA models and considers 10 components. From these components, there are 9 dissolved components and one particulate component corresponding to microalgae biomass $\left(X_{A L G}\right)$.

\section{Dissolved components}

1. $\mathbf{S}_{\mathrm{NH} 4}\left[\mathrm{gNH}_{4}{ }^{+}-\mathrm{N} / \mathrm{m}^{3}\right]$ : Ammonium nitrogen.Nitrogen present in the wateras ammonium. It is produced through the processes of endogenous respiration and through inactivation of microalgae. It is consumed through the growth of microalgae. 
2. $\mathbf{S}_{\mathrm{NH} 3}\left[\mathrm{gNH}_{3}-\mathrm{N} / \mathrm{m}^{3}\right]$ : Ammonia nitrogen. Nitrogen in the form of ammonia. It is in chemical equilibrium with ammonium $\left(S_{N H 4}\right)$. Its concentration decreases by volatilization to the atmosphere.

3. $\mathbf{S}_{\mathrm{NO} 3}\left[\mathrm{gNO}_{3}{ }^{-}-\mathrm{N} / \mathrm{m}^{3}\right]$ :Nitrate nitrogen.Nitrogen available as nitrate. It is consumed by microalgae $\left(X_{A L G}\right)$.

4. $\mathbf{S}_{\mathbf{O} 2}\left[\mathrm{gO}_{2} / \mathrm{m}^{3}\right]$ :Dissolved oxygen. Concentration of dissolved oxygen in the water. It is produced by the growth of microalgae due to photosynthesis and consumed during the processes of endogenous respiration and inactivation of microalgae. It can also be transferred to the atmosphere.

5. $\mathbf{S}_{\mathbf{C O} 2}\left[\mathrm{gCO}_{2}-\mathrm{C} / \mathrm{m}^{3}\right]$ :Carbondioxide. Carbon as carbondioxide. It is consumed by microalgae and is produced through the processes of endogenous respiration and inactivation.Moreover, it is in chemical equilibrium with bicarbonate $\left(S_{\mathrm{HCO} 3}\right)$ and carbonate $\left(\mathrm{S}_{\mathrm{CO} 3}\right)$, and like dissolved oxygen $\left(S_{O 2}\right)$, it can be transferred to the atmosphere.

6. $\mathrm{S}_{\mathrm{HCO} 3}\left[\mathrm{gHCO}_{3}{ }^{-} \mathrm{C} / \mathrm{m}^{3}\right]$ : Bicarbonate.Carbon as bicarbonate. It is in chemical equilibrium with carbon dioxide $\left(S_{\mathrm{CO} 2}\right)$ and carbonate $\left(S_{\mathrm{CO} 3}\right)$.It is consumed by microalgae.

7. $\mathbf{S}_{\mathrm{CO} 3}\left[\mathrm{gCO}_{3}{ }^{2-}-\mathrm{C} / \mathrm{m}^{3}\right]$ : Carbonate.Carbon in the form of dissolved carbonate. It is in chemical equilibrium with bicarbonate $\left(\mathrm{S}_{\mathrm{HCO} 3}\right)$ and carbon dioxide $\left(\mathrm{S}_{\mathrm{CO} 2}\right)$. Carbonate is not used by microalgae as carbon source.

8. $\mathbf{S}_{\mathbf{H}}\left[\mathrm{gH} / \mathrm{m}^{3}\right]:$ Hydrogen ions. Concentration of hydrogen ions in the water. They are involved in carbon and ammonium equilibrium systems. The concentration of hydrogen ions decreases with the growth of microalgae and increases with endogenous respiration and inactivation.

9. $\mathbf{S}_{\mathbf{O H}}\left[\mathrm{gOH}^{-}-\mathrm{H} / \mathrm{m}^{3}\right]:$ Hydroxide ions. Concentration of hydroxide ions in the water. They are in equilibrium with hydrogen ions.

\section{Particulate components}

10. $\mathbf{X}_{\mathrm{ALG}}\left[\mathrm{gCOD} / \mathrm{m}^{3}\right]$ : Microalgae biomass. Concentration of microalgae. It increases with growth processes and decreases by endogenous respiration and inactivation. Note that it is expressed in gCOD (chemical oxygen demand) $/ \mathrm{m}^{3}$ as it is common practice to express organic matter concentrations in all IWA models. Microalgae biomass is transformed from COD to TSS (total suspended solids) assuming a ratio COD/TSS $=0.80$ (Sperling, 2007; Khorsandi et al., 2014).

\subsection{Processes}

Table 1 shows a list of the processes included in the model and the equations describing their rates. Table 2 shows the matrix of stoichiometric parameters. 
151

152

153

154

155

156

157

158

159

160 
Table 1.Mathematical description of the processes of the model (processes rates).

\begin{tabular}{|c|c|}
\hline Processes & Process rate $\left[\mathrm{M} \mathrm{L}^{-3} \mathbf{T}^{-1}\right]$ \\
\hline 1a. Microalgae growth on ammonia & $\rho_{1 a}=\mu_{A L G} * f_{T, F S}(T) * \eta_{P S}\left(I, S_{O 2}\right) * \frac{S_{C O 2}+S_{H C O 3}}{K_{C, A L G}+S_{C O 2}+S_{H C O 3}+\frac{S_{C O 2}{ }^{2}}{I_{C O 2} A L G G}} * \frac{S_{N H 3}+S_{N H 4}}{K_{N, A L G}+S_{N H 3}+S_{N H 4}} * X_{A L G}$ \\
\hline 1b. Microalgae growth on nitrate & $\rho_{1 b}=\mu_{A L G} * f_{T, F S}(T) * \eta_{P S}\left(I, S_{O 2}\right) * \frac{S_{C O 2}+S_{H C O 3}}{K_{C, A L G}+S_{C O 2}+S_{H C O 3}+\frac{S_{C O 2^{2}}{ }^{2}}{I_{C 2} A G G}} * \frac{S_{N O 3}}{K_{N, A L G}+S_{N O 3}} * \frac{K_{N, A L G}}{K_{N, A L G}+S_{N H 3}+S_{N H 4}} * X_{A L G}$ \\
\hline 2. Microalgae endogenous respiration & $\rho_{2}=k_{r e s p, A L G} * f_{T, F S}(T) * \frac{S_{O 2}}{K_{O 2, A L G}+S_{O 2}} * X_{A L G}$ \\
\hline 4.Chemical equilibrium $\mathrm{CO}_{2} \leftrightarrow \mathrm{HCO}_{3}^{-}$ & $\rho_{4}=k_{e q, 1} *\left(S_{C O 2}-\frac{S_{H} S_{H C O 3}}{K_{e q, 1}}\right)$ \\
\hline 5. Chemical equilibrium $\mathrm{HCO}_{3}^{-} \leftrightarrow \mathrm{CO}_{3}^{2-}$ & $\rho_{5}=k_{e q, 2} *\left(S_{H C O 3}-\frac{S_{H} S_{C O 3}}{K_{e q, 2}}\right)$ \\
\hline 6. Chemical equilibrium $N H_{4}^{+} \leftrightarrow N_{3}$ & $\rho_{6}=k_{e q, 3} *\left(S_{N H 4}-\frac{S_{H} S_{N H 3}}{K_{e q, 3}}\right)$ \\
\hline 7. Chemical equilibrium $H^{+} \leftrightarrow O H^{-}$ & $\rho_{7}=k_{e q, w} *\left(1-\frac{S_{H} S_{O H}}{K_{e q, w}}\right)$ \\
\hline 10. Ammonia transfer to the atmosphere & $\rho_{N H 3}=K a, \mathrm{NH} 3 *\left(S_{N H 3}^{W A T}-S_{N H 3}\right)$ \\
\hline
\end{tabular}




\begin{tabular}{|c|c|c|c|c|c|c|c|c|c|c|c|}
\hline State variables $\rightarrow i$ & & $\mathbf{S}_{\mathrm{NH} 4}$ & $\mathbf{S}_{\mathrm{NH} 3}$ & $\mathbf{S}_{\mathrm{NO} 3}$ & $S_{02}$ & $\mathbf{S}_{\mathrm{CO} 2}$ & $\mathbf{S}_{\mathrm{HCO} 3}$ & $\mathbf{S}_{\mathrm{CO} 3}$ & $\mathbf{S}_{\mathrm{H}}$ & $\mathrm{S}_{\mathrm{OH}}$ & $\mathbf{X}_{\mathrm{ALG}}$ \\
\hline Processes $\downarrow j$ & & $\mathrm{gN} / \mathrm{m}^{3}$ & $\mathrm{gN} / \mathrm{m}^{3}$ & $\mathrm{gN} / \mathrm{m}^{3}$ & $\mathrm{gO}_{2} / \mathrm{m}^{3}$ & $\mathrm{gC} / \mathrm{m}^{3}$ & $\mathrm{gC} / \mathrm{m}^{3}$ & $\mathrm{gC} / \mathrm{m}^{3}$ & $\mathrm{gH} / \mathrm{m}^{3}$ & $\mathrm{gH} / \mathrm{m}^{3}$ & $\mathrm{gCOD} / \mathrm{m}^{3}$ \\
\hline 1a. Microalgae growth on ammonia & $\rho_{1 a}$ & $v_{1,1 a}$ & & & $v_{4,1 a}$ & $v_{5,1 a}$ & & & $v_{8,1 a}$ & & $\mathrm{v}_{10,1 \mathrm{a}}$ \\
\hline 1b. Microalgae growth on nitrate & $\rho_{1 b}$ & & & $v_{3,1 b}$ & $v_{4,1 b}$ & $v_{5,1 b}$ & & & $v_{8,1 b}$ & & $\mathrm{v}_{10,1 \mathrm{~b}}$ \\
\hline 2. Microalgae endogenous respiration & $\rho_{2}$ & $v_{1,2}$ & & & $v_{4,2}$ & $v_{5,2}$ & & & $v_{8,2}$ & & $\mathrm{v}_{10,2}$ \\
\hline 3. Microalgae inactivation & $\rho_{3}$ & $v_{1,3}$ & & & $v_{4,3}$ & $v_{5,3}$ & & & $v_{8,3}$ & & $\mathrm{v}_{10,3}$ \\
\hline 4. Chemical equilibrium $\mathrm{CO}_{2} \leftrightarrow \mathrm{HCO}_{3}^{-}$ & $\rho_{4}$ & & & & & $v_{5,4}$ & $v_{6,4}$ & & $v_{8,4}$ & & \\
\hline 5. Chemical equilibrium $\mathrm{HCO}_{3}^{-} \leftrightarrow \mathrm{CO}_{3}^{2-}$ & $\rho_{5}$ & & & & & & $v_{6,5}$ & $v_{7,5}$ & $v_{8,5}$ & & \\
\hline 6. Chemical equilibrium $N H_{4}^{+} \leftrightarrow N_{3}$ & $\rho_{6}$ & $v_{1,6}$ & $v_{2,6}$ & & & & & & $v_{8,6}$ & & \\
\hline 7. Chemical equilibrium $H^{+} \leftrightarrow \mathrm{OH}^{-}$ & $\rho_{7}$ & & & & & & & & $v_{8,7}$ & $v_{9,7}$ & \\
\hline 8. Oxygen transfer to the atmosphere & $\rho_{02}$ & & & & $v_{4,02}$ & & & & & & \\
\hline 9.Carbon dioxide transfer to the atmosphere & $\rho_{\mathrm{CO} 2}$ & & & & & $v_{5, \mathrm{CO} 2}$ & & & & & \\
\hline 10. Ammonia transfer to the atmosphere & $\rho_{N H 3}$ & & $v_{2, \mathrm{NH} 3}$ & & & & & & & & \\
\hline
\end{tabular}




\section{Algal processes}

- Growth of microalgae(processes 1a and 1b in Table 1). The increase of microalgae biomass per unit of time (growth rate) is expressed as the product of their maximum specific growth rate $\left(\mu_{A L G}\right)$ by their concentration at that point in time $\left(X_{A L G}\right)$ and by correctivefactors (in the form of Monod functions) that limit or inhibit their growth.

Microalgae grow with both carbon dioxide $\left(\mathrm{S}_{\mathrm{CO} 2}\right)$ and bicarbonate $\left(\mathrm{S}_{\mathrm{HCO} 3}\right)$. Note that in the matrix of stoichiometric parameters (Table 2) only the reactionrate of carbondioxideis affected by microalgae growth because the concentration of bicarbonate is already in chemical equilibrium with it.Carbon dioxide $\left(S_{\mathrm{CO} 2}\right)$ inhibits microalgae growthat very high concentrations based on the results of Silva and Pirt(1984).More precisely,it has been observed that in closed photobioreactors $\mathrm{CO}_{2}$ behaves as an inhibitor at partial pressuresabove0.6 atm, which is equivalent to a dissolved $\mathrm{CO}_{2}$ concentration of $440 \mathrm{mgCO}_{2} / \mathrm{L}$ at $37{ }^{\circ} \mathrm{C}($ Silva and Pirt, 1984). Inhibition caused by $\mathrm{CO}_{2}$ is due to the compound itself as well as its effect on acidity, which in the current status of the model can not be distinguished.Microalgae grow with ammonia and ammonium $\left(S_{N H 4}-S_{N H 3}\right)$ or with nitrate $\left(S_{N O 3}\right)$ as nitrogen source. When ammonium (or ammonia, note that they are in chemical equilibrium) and nitrate are both present, ammonium is generally preferred (Stewart, 1974;Syrett, 1981;Monstert and Grobbelar, 1987). To represent this phenomenon, the highlighted term that describes the inhibiting effect of ammonia and ammonium on growth of microalgae once nitrate has been introduced in Eq. (1) (process $1 \mathrm{~b}$ in Table 1).

$$
\rho_{1 b}=\mu_{A L G} * f_{T, F S}(T) * \eta_{P S}\left(I, S_{O 2}\right) * \frac{S_{C O 2}+S_{H C O} 3}{K_{C, A L G}+S_{C O 2}+S_{H C O}+\frac{S_{C O 2}{ }^{2}}{I_{C O}, A L G}} * \frac{S_{N O 3}}{K_{N, A L G}+S_{N O 3}} * \frac{K_{N, A L G}}{K_{N, A L G}+S_{N H 3}+S_{N H 4}} * X_{A L G}(1)
$$

Here again note that microalgae growth onlyaffects the reaction rate of ammonia because it is in equilibrium with ammonium (Table 2).

The photosynthetic factor $\left(\eta_{P S}\right)$ takes into account the effects of light intensity $(I)$ and excess of oxygen $\left(S_{O 2}\right)$ on photosynthesis and therefore on microalgae growth.The following relationship was introduced:

$$
\eta_{P S}\left(I, S_{O 2}\right)=f_{L}(I) \cdot f_{P R}\left(S_{O 2}\right)
$$

where, $f_{L}$ is the light factor and $f_{P R}$ the photorespiration factor.

The effects of light intensity on photosynthesis are described by the 'photosynthetic factories' model (PSF) as proposed by Eilers and Peeters (1988): at low light irradiance, the rate of photosynthesis is proportional to light intensity because photosynthesis is limited by the rate of capture of photons. When irradiance increases to a certain point, microalgae become 'light saturated' because photosynthesis cannot process more photons. If irradiance increases beyond an inhibitory threshold, the rate of photosynthesis starts to decrease (Crill, 1977; Camacho-Rubio et al., 2003; Béchet et al., 2013). 
In the PSF model it is assumed that microalgae are present in three different states: resting or 'open' $\left(\mathrm{x}_{1}\right)$, activated or 'closed' $\left(\mathrm{x}_{2}\right)$, and inhibited $\left(\mathrm{x}_{3}\right)$ (Figure 2$)$.

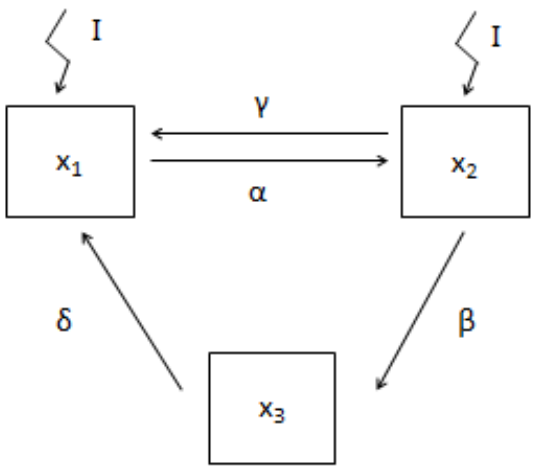

Figure 2.Three different states and relationships of the photosynthetic factories model (PSF): open $\left(\mathrm{x}_{1}\right)$, closed $\left(\mathrm{x}_{2}\right)$ and inhibited $\left(\mathrm{x}_{3}\right)$ (Adapted from Eilers and Peeters $(1998)$ ).

Initially microalgae are in open state $x_{1}$, ready to capture a photon. When the photon is captured and biochemical reactions start,microalgae turn to activated state $x_{2}$. This reaction depends on the rate of activation $\alpha$ $\left[\left(\mu \mathrm{E} / \mathrm{m}^{2}\right)^{-1}\right]$. In activated state microalgae can go back to open state $x_{1}$ in dark conditions, or can capture another photon and pass to inhibited state $x_{3}$. These two reactions depend on a rate constant of production $\gamma\left[\mathrm{s}^{-1}\right]$ and on a rate constant of inhibition $\beta\left[\left(\mu \mathrm{E} / \mathrm{m}^{2}\right)^{-}\right.$ $\left.{ }^{1}\right]$. Microalgae in the inhibited state turn back to the open state with a rate of recovery $\delta\left[\mathrm{s}^{-1}\right]$.

Considering the principle of mass conservation, the three states can be described by the followingsystem ofdifferential equations (Equation 3, 4,5 and 6):

$$
\frac{d x_{1}}{d t}=-\alpha \cdot I \cdot x_{1}+\gamma \cdot x_{2}+\delta \cdot x_{3}(3)
$$

$\frac{d x_{2}}{d t}=\alpha \cdot I \cdot x_{1}-\gamma \cdot x_{2}-\beta \cdot I \cdot x_{2}(4)$

$\frac{d x_{3}}{d t}=\beta \cdot I \cdot x_{2}-\delta \cdot x_{3}(5)$

$x_{1}+x_{2}+x_{3}=1(6)$

When irradiance is not constant, but is a nonlinear function of time $(I(\mathrm{t}))$, this system ofdifferential equations does not havean analytical solution. However, under outdoor conditions, variations of $I$ during the daily solar cycle are very slowwith respect to the dynamics of photosynthesis (Eilers and Peeters, 1988, Camacho-Rubio et al., 2002,). In these conditions $x_{1}$ and $x_{2}$ are close to equilibrium within less than a second. Therefore it can be assumed that equilibrium is reached instantly, making the left hand side of differential terms equal to zero. Under this assumption, the solution to this system of differential equations is:

$$
\begin{aligned}
& x_{1}=\frac{\gamma \delta+\beta I \delta}{\alpha \beta I^{2}+(\alpha+\beta) \delta I+\gamma \delta}(7) \\
& x_{2}=\frac{\alpha \delta I}{\alpha \beta I^{2}+(\alpha+\beta) \delta I+\gamma \delta}(8)
\end{aligned}
$$


247 The state in which microalgae can grow is $x_{2}$, and therefore in our model the 248 photosynthetic factor is:

249

$$
f_{L}(I)=x_{2}(10)
$$

As shown before (Eq. 2), in microalgae cultures photosynthesis not only depends on the solar irradiance, but is also a function of oxygen concentration(for high concentrations). Especially in closed photobioreactors where there is little (if any) oxygen exchange with the atmosphere, the accumulation of this component may inhibit photosynthesis (Molina-Grima et al., 2001). According to Chisti (2007), toprevent suchinhibitory effects the dissolved oxygen concentrationshould never exceedabout $400 \%$ of air saturation value. The photorespiration factoris introduced in this work torepresent this phenomenon in mathematical terms:

$f_{P R}\left(S_{O 2}\right)=\left\{\begin{array}{c}1-\tanh \left(\frac{K_{P R} \cdot \frac{S_{O 2}}{\tau \cdot S_{O 2}^{S A T}}}{1-\frac{S_{O 2}}{\tau \cdot S_{O 2}^{S A T}}}\right), \quad S_{O 2} \leq \tau \cdot S_{O 2}^{S A T} \\ 0, \quad S_{O 2}>\tau \cdot S_{O 2}^{S A T}\end{array}\right.$

where $S_{O 2}{ }^{S A T}\left[\mathrm{gO}_{2} / \mathrm{m}^{3}\right]$ is the saturation concentration of oxygen in the air. The photorespiration inhibition constant $\left(K_{P R}\right)$ and the coefficient of excess dissolved oxygen $(\tau)$ are parameters that have to be calibrated during the application of the model.

The effect of photorespiration does notaffect microalgal production if the concentration of oxygen in water is clearly lower than $\tau$ times the saturation concentration, as is the case of open photobioreactors (Chisti, 2007). However, when the concentration of oxygen tends towards saturation $\left(\tau S_{O 2}{ }^{S A T}\right)$ the photorespiration factor decreases, hindering microalgae growth.

The thermic photosynthetic factor $\left(f_{T, F S}\right)$ takes into account the effects of temperature on microalgae growth and also on endogenous respiration and inactivation processes (1a, 1b,2 and 3 in Table 1, respectively). Water temperature varies on both diurnal and seasonal scales, affecting both microalgal photosynthesis and respiration rates.The optimal temperature for algal growth ranges between $15^{\circ} \mathrm{C}$ and $25^{\circ} \mathrm{C}$, depending on the species (Larsdotter, 2006; Bitog et al., 2011). The thermic photosynthetic factor is represented in the model following the work of Dauta et al. (1990):

$\mathrm{f}_{\mathrm{T}, \mathrm{FS}}(\mathrm{T})=e^{-\left(\frac{T-T o p t}{s}\right)^{2}}$

where $\mathrm{T}_{\text {opt }}$ Was assumed equal to $25^{\circ} \mathrm{C}$ (Dauta et al., 1990) and $s$ is aparameter value for empirical fitting. 
-Endogenous respiration(process 2 in Table 1). The rate of this process is expressed as the product betweenthe maximum rate of endogenous respiration $\left(k_{\text {resp, alg }}\right)$, the concentration of microalgae, the thermic photosynthetic factor(the same as used for the growth of microalgae) and Monod function relates limiting oxygen concentration to a microalgae growth rate.

- Inactivation of microalgae(process 3 in Table 1). The rate of this process is expressed as the product of the maximum rate of inactivation $\left(k_{\text {death,alg }}\right)$ by the concentration of microalgae and by thermic photosynthetic factor (the same as for growth) (Reichert et al., 2001).

\section{Chemical equilibrium reactions}

Chemical equilibria affect carbon, nitrogen and the balance of hydrogen and hydroxide ions (processes 4, 5, 6 and 7 in Table 1). The rates of these chemical reactions $\left(\rho_{i}\right)\left[\mathrm{g} \cdot \mathrm{m}^{-3} \cdot \mathrm{d}^{-1}\right]$ are obtained with the following general equation(Batstone et al., 2002):

$$
\rho_{i}=K e q, i\left(S_{i}-S_{e q, i}\right)(13)
$$

Where $i=1 \ldots n$ and $n$ is the number of chemical species in equilibrium, $k_{e q, i}\left[\mathrm{~d}^{-1}\right]$ is the dissociation constant of reaction $i, S_{i}\left[\mathrm{~g} / \mathrm{m}^{3}\right]$ is the concentration of the $i^{\text {th }}$ component and $S_{e q, i}\left[\mathrm{~g} / \mathrm{m}^{3}\right]$ is the concentration at equilibrium.

\section{Transfer of gases to the atmosphere}

Transfer rates of oxygen, carbondioxide and ammonia between water and the atmosphere (processes 8, 9 and 10 in Table 1) are given by thegeneral equation(Batstone et al., 2002):

$$
\rho_{j}=K a, j\left(S_{j}^{W A T}-S_{j}\right)
$$

where $j=1 \ldots \mathrm{m}$ and $\mathrm{m}$ is the number of transfer rates, $S_{j}^{W A T}\left[\mathrm{~g} / \mathrm{m}^{3}\right]$ is the saturation concentration of $j^{\text {th }}$ gas in the water, $S_{j}\left[\mathrm{~g} / \mathrm{m}^{3}\right]$ is the gas concentration in the water and $K_{a, j}$ is the overall mass transfer coefficient of $\mathrm{j}^{\mathrm{th}}$ gas $\left[\mathrm{d}^{-1}\right] . K_{a}$ depends on the temperature, the nature of the gas and the liquid and the extension of the surface interface.

\subsection{Effects of temperature, irradianceand $\mathrm{pH}$}

Temperature,irradiance andpH also affect the rates the processes described previously.

Irradiance $(\mathbf{I}(\lambda))\left[\mu \mathrm{E} /\left(\mathrm{m}^{2} \mathrm{~s}\right)\right]$ :Wavelength-specific Irradiance or light intensity.It isalso known in literature as a photon flux density (PFD). 
In the present model irradiance was expressedas photosyntheticallyactive radiation (PAR), which includes wavelengths between 400 and $700 \mathrm{~nm}$ (Zonneveld, 1998):

$$
\operatorname{PAR}=\int_{400 \mathrm{~nm}}^{700 \mathrm{~nm}} I(\lambda) d \lambda(15)
$$

If measured PAR values are not available, estimated values at any Earth geographical location can be calculated from coordinates with the equations presented in Table 3 (Al-Rawahi et al., 2011).

Table 3 - Mathematical equations for estimating irradiance at any point on Earth. Parameters and factors are described in Supplementary Table 1.

\begin{tabular}{|c|c|c|}
\hline Description & Mathematical Equation & Units \\
\hline $\begin{array}{l}\text { Total incident solar } \\
\text { irradiation }\end{array}$ & $\begin{aligned} \mathrm{I}_{0}=\frac{\pi H E_{\mathrm{f}}}{24}\{[0.409 & \left.+0.5016 \cdot \sin \left(\omega_{\mathrm{s}}-60\right)\right] \\
& \left.+\left[0.6609-0.4767 \cdot\left(\omega_{\mathrm{s}}-60\right)\right] \cos \omega\right\} \\
& \times\left(\frac{\cos \omega \cdot \cos \omega_{\mathrm{s}}}{\sin \omega_{c}-\omega_{c} \cdot \cos \omega_{c}}\right) \cdot 0,2174\end{aligned}$ & $\mu \mathrm{E} /\left(\mathrm{m}^{2} \mathrm{~s}\right)$ \\
\hline Daily radiation & $\mathrm{H}=\aleph \mathrm{H}_{0}$ & $\mathrm{~J} /\left(\mathrm{m}^{2} \mathrm{~d}\right)$ \\
\hline $\begin{array}{l}\text { Total daily } \\
\text { extraterrestrial radiation }\end{array}$ & $\begin{array}{c}H_{0}=\left(\frac{24 \zeta}{\pi}\right)\left(1+0.003 \cdot \cos \left(\frac{360 N}{365}\right)\right)\left(\cos \phi \cdot \cos \delta \cdot \sin \omega_{s}+\frac{2 \pi \omega_{s}}{360}\right. \\
\cdot \sin \phi \cdot \sin \delta)\end{array}$ & $\mathrm{J} /\left(\mathrm{m}^{2} \mathrm{~d}\right)$ \\
\hline
\end{tabular}

Water temperature $\left(\mathbf{T}\left[{ }^{\circ} \mathrm{C}\right]\right)$ : Watertemperature. Microalgae processes are influenced by temperature described by thermic photosynthetic factor Eq. (12).

$\mathbf{p H}[-] . \mathrm{pH}$ of the aqueous medium is obtained from hydrogen ions concentration $\left(S_{H}\right) \cdot \mathrm{pH}$ value displaces the equilibrium of the carbon and nitrogen species.

\subsection{Stoichiometry and parameter values}

The stoichiometric matrix is presented in Table 2and is based on the structure of IWA models (Petersen matrix).Values of biokinetic, physical and chemical parameters are shown in Supplementary Tables 1-2. Mathematical expressions of the stoichiometric coefficients of each processare shown in Supplementary Table 3-4.

Using Tables 1and 2, the reaction rate for each component of the model $\left(r_{i}\right)$ is obtained with:

$$
r_{i}=\sum_{j} v_{j, i} * \rho_{j}(15)
$$

where $i$ is the number of components and $j$ is the number of processes; $\rho_{j}$ is the reaction rate for each process $j$ and $v_{i, j}$ is the stoichiometric coefficient. The expressions of stoichiometric coefficients related to microalgae processes are based onthe fractions of carbon $\left(i_{C, A L G}\right)$, hydrogen $\left(i_{H, A L G}\right)$, oxygen $\left(i_{O, A L G}\right)$ and nitrogen $\left(i_{N, A L G}\right)$ (Appendix, Table 6 and 7). 


\section{Experimental verification}

Experiments were carried out in a batch mesocosm microalgae culture located outdoors at the facilities of the Laboratory of Environmental Biotechnology (LBE, INRA) in Narbonne, South of France $\left(43^{\circ} 11^{\prime} \mathrm{N}, 3^{\circ} 00^{\prime} \mathrm{E}, 13 \mathrm{~m}\right.$ A.M.S.L.).The mesocosm consisted ofa cylindrical PVC container with a surface area of $1.30 \mathrm{~m}^{2}$ and a depth of $0.55 \mathrm{~m}$ (nominal volume $500 \mathrm{~L}$ ).A drainage pump ensuredcontinuous stirringofculture medium.

Experiments started on January $23^{\text {rd }}$ 2012. The mesocosm (without replicates) was manually filled with $450 \mathrm{~L}$ of medium. $50 \mathrm{~L}$ of inoculum with the microalgae Scenedemussp were added. The medium was prepared as to simulate the mineral composition of a wastewater. A commercial mineral fertilizer (Antys8, Frayssinet, France) $\left(80 \mathrm{~g} / \mathrm{LTN}, 50 \mathrm{~g} / \mathrm{LP}_{2} \mathrm{O}_{5}\right)$ was diluted into tap water $(0.16 / 1000)$, and $0.03 \mathrm{~g} / \mathrm{L}$ of $\mathrm{NH}_{4} \mathrm{Cl}$ were added to increase nitrogen concentration. The experiments lasted 9 days, and no new fresh medium was added during the entire experimental period.

Photosynthetically active radiation (PAR) was measuredwitha probe(Sky Instruments PAR Quantum Sensor) located on the surface of mesocosms; data were recorded every five minutes.Water temperature and $\mathrm{pH}$ were measuredwith $\mathrm{pH}$ and temperature probes (InPro 426i, Mettler Toledo, $\mathrm{CH}$ ) every morning.During the 9 days water temperature varied between 9and $18.7^{\circ} \mathrm{C}$ (January and February are the coldest months in the region) and the light intensity (PAR)ranged from 3.25 and $655 \mu \mathrm{E} / \mathrm{m}^{2} * \mathrm{~s}$.

Samples of the microalgae culture were taken after2, 4, 8 and 9days, and analyzed for total suspended solids (TSS) as indicator of algal biomassand ammonium $\left(\mathrm{NH}_{4}{ }^{+}-\mathrm{N}\right)$ according to conventional procedures indicated in the Standard Methods (APHA-AWWA-WPCF, 2001).

\section{Model implementation and calibration procedure}

The modeldescribed in section 2was implemented in COMSOL Multiphysics ${ }^{\mathrm{TM}} \mathrm{v} 4.3 \mathrm{~b}$ software.A0D domain was used to represent the experimental reactor (mesocosms), which can be considered in perfect mixing, and therefore transport of aqueous phase species (i.e. dissolved and particulate) can be ignored.

The model was calibrated using available data for the 9 days of experimentation. Manual trial and error adjustment of parameters was used to match measured data as much as possible using graphical representations.

The concentrations of componentsin the mesocosmsmeasured at the beginning of the experiment are shown in Table 3.

Table 3.Initial concentrations of the componentsin the mesocosms.

\begin{tabular}{|c|c|c|}
\hline Component & Concentration & Units \\
\hline \multicolumn{2}{|l|}{} \\
\hline Dissolved Components \\
\hline $\mathbf{S}_{\mathrm{NH} 4}$ & 8.1 & $\mathrm{gN}-\mathrm{NH}_{4} / \mathrm{m}^{3}$ \\
\hline $\mathbf{S}_{\mathrm{NH} 3}$ & 0.685 & $\mathrm{gN}-\mathrm{NH}_{3} / \mathrm{m}^{3}$ \\
\hline
\end{tabular}




\begin{tabular}{|c|c|c|}
\hline $\mathbf{S}_{\mathrm{NO} 3}$ & 11.37 & $\mathrm{gN}-\mathrm{NO}_{3} / \mathrm{m}^{3}$ \\
\hline $\mathrm{S}_{\mathrm{CO} 2}$ & 0.8 & $\mathrm{gC}-\mathrm{CO}_{2} / \mathrm{m}^{3}$ \\
\hline $\mathrm{S}_{\mathrm{HCO} 3}$ & 100 & $\mathrm{gC}-\mathrm{HCO}_{3} / \mathrm{m}^{3}$ \\
\hline $\mathbf{S}_{\mathrm{CO} 3}$ & 1.17 & $\mathrm{gC}-\mathrm{CO}_{3} / \mathrm{m}^{3}$ \\
\hline $\mathbf{S}_{\mathrm{O} 2}$ & 8 & $\mathrm{gO}_{2} / \mathrm{m}^{3}$ \\
\hline$S_{H}$ & $3.16^{*} 10^{-6}$ & $\mathrm{gH} / \mathrm{m}^{3}$ \\
\hline $\mathrm{S}_{\mathrm{OH}}$ & $2.83 * 10^{-3}$ & $\mathrm{gH}-\mathrm{OH} / \mathrm{m}^{3}$ \\
\hline \multicolumn{3}{|c|}{ Particulate Component } \\
\hline $\mathbf{X}_{\mathrm{ALG}}$ & 100 & $\mathrm{gTSS} / \mathrm{m}^{3}$ \\
\hline
\end{tabular}

From the 31 parameters implemented in the model, 16 parameters were obtained from the existing River Water Quality Model (Reichert et al., 2001). Those parameters related to transfer of gases to the atmosphere, temperature, photorespiration and carbon limitation on microalgae growthare not included into the RWQM1 and they were obtained from other literature cited in Tables. Morris's uncertainty method (Morris, 1991) was applied to screening which parameters had a greater influence on the simulation response. Based on a previous uncertainty analysis, the model was calibrated by adjusting the values of the maximum growth rate of microalgae $\left(\mu_{A L G}\right)$, the transfer of gases to the atmosphereand the photorespiration inhibition constant $\left(K_{P R}\right)$.Calibration was conducted by comparing simulated and experimental data curves.

\section{Results}

Biomass concentration in the mesocosm increased from $100 \mathrm{gTSS} / \mathrm{m}^{3}$ at the beginning of the experiment to around $210 \mathrm{gTSS} / \mathrm{m}^{3}$ after 9 days.Figure 3 shows that the model was able to reproduce such growth pattern with an acceptable accuracy. Interestingly, the simulated curve has a waveliketrend which indicates that the model is able to reproduce microalgae growth (crests) and inactivation (trough) cycles occurring during daytime and at night, respectively.

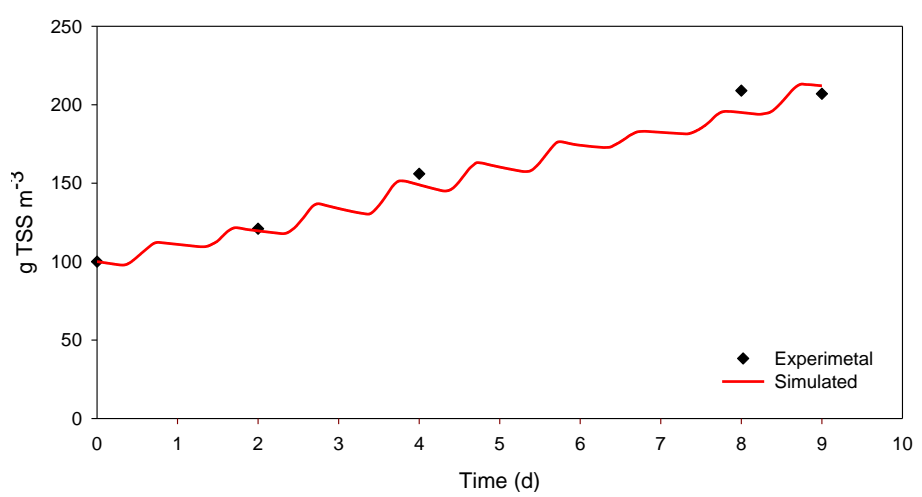

Figure 3.Experimental (black dots) and simulated (red line) microalgae biomass growth over the 9 days. The crests and troughs of the simulated curve correspond to microalgae growth and inactivation periods during daytime and at night, respectively.

On the other hand, Figure 4 shows that $\mathrm{pH}$ increased with the growth of microalgae. Despite the fitting between experimental data and simulation results are not as good as in Figure 3, the model still predicts the general trend shown by the 
experimentally measured $\mathrm{pH}$ values.Again, daily $\mathrm{pH}$ variations related to the activity of 413 microalgae can be clearly observed. In darkness, the $\mathrm{pH}$ decreases as a consequence of 414 endogenous respiration and inactivation of microalgaewhich release both carbon dioxide and hydrogen ions, while during the day the $\mathrm{pH}$ increases due to photosynthesis.

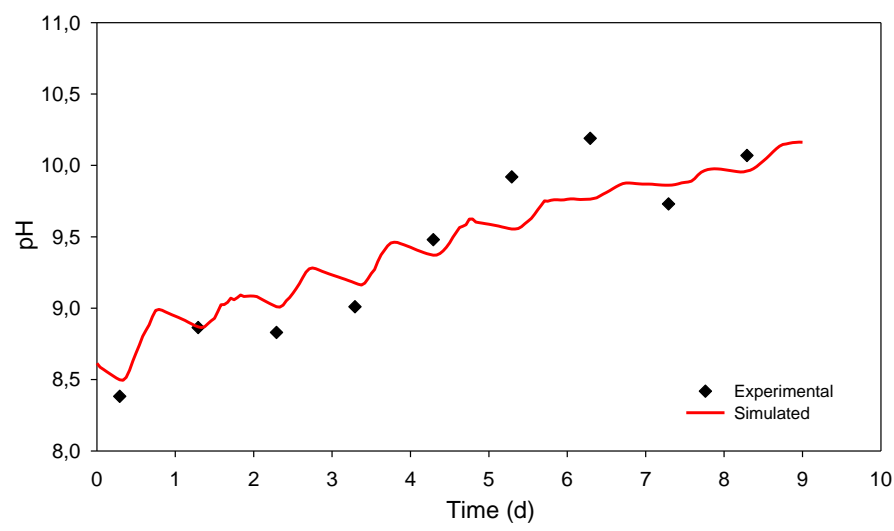

Figure 4.Experimental (black dots) and simulated (red line) $\mathrm{pH}$ values over the 9 days period.

Figure 5 showsthe experimental and simulatedammonium nitrogen concentrations within the mesocosm as well as the simulated nitrate concentration (note that nitrate concentrations were not measured in the experimental study). Once more, the simulated ammonium concentrations match the trend of the experimental measurements with a satisfactory degree of accuracy. Although this phenomenon cannot be demonstrated with the available experimental data, Figure 5 also showsto what extentmicroalgae growth used ammonium preferably to nitrate as nitrogen source. After 6 days, the concentrations of $\mathrm{S}_{\mathrm{NH} 4}$ and $\mathrm{S}_{\mathrm{NH} 3}$ were very low but microalgae continued growing, most likelyby consuming $\mathrm{S}_{\mathrm{NO} 3}$. Once again, the daily $\mathrm{S}_{\mathrm{NH} 4}+\mathrm{S}_{\mathrm{NH} 3}$ variations related to the activity of microalgaecan be clearly observed.

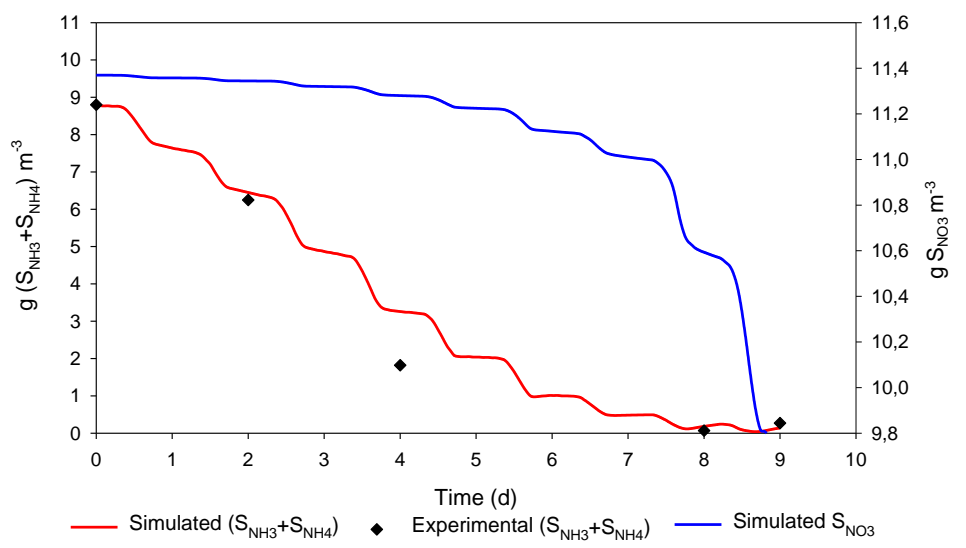

Figure 5.Comparison between experimental (dots) and simulated (red line) concentrations of ammonium and ammonia and simulated concentrationsof nitrate (blue line).

Figure 6 shows simulation results for $\mathrm{S}_{\mathrm{CO} 2}+\mathrm{S}_{\mathrm{HCO} 3}$ and $\mathrm{S}_{\mathrm{CO} 3}$ concentrations. $\mathrm{S}_{\mathrm{CO} 2}+\mathrm{S}_{\mathrm{HCO} 3}$ decreased with the growth of microalgae while the concentration of 
$\mathrm{S}_{\mathrm{CO} 3}$ followed the opposite trend. For increasing values of $\mathrm{pH}$, the equilibrium of the carbon species isdisplaced towards the formation of carbonates $\mathrm{CO}_{3}{ }^{2-}$. Daily variations of these carbon species are again related to growth and endogenous respiration and inactivation cycles during daytime and at night, respectively.

Figure 6. Microalgae uptake of carbon $\left(\mathrm{S}_{\mathrm{HCO} 3}+\mathrm{S}_{\mathrm{CO} 2}\right.$ ) (red line) and $\mathrm{S}_{\mathrm{CO} 3}$ (blue line) simulated curves.

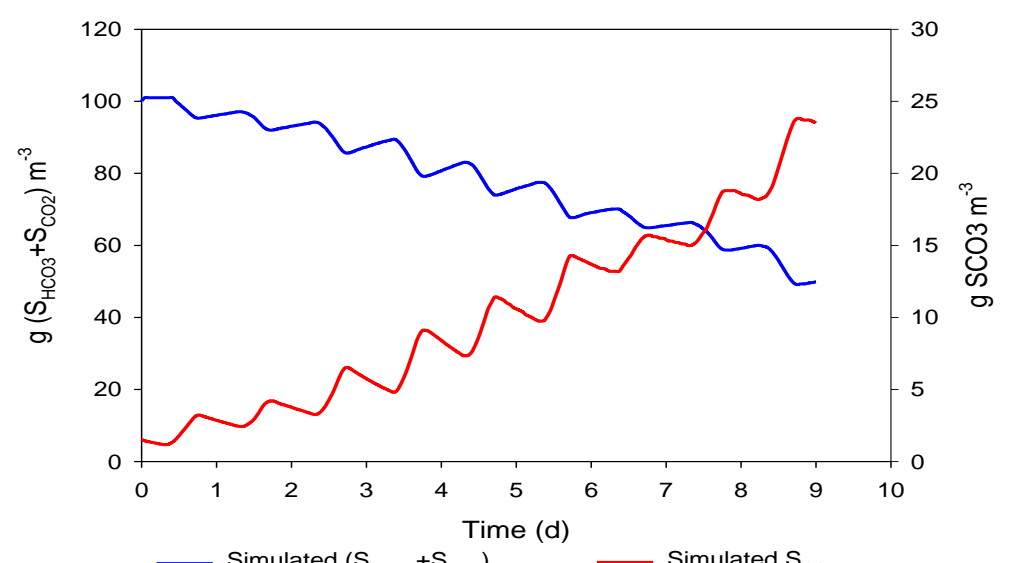

The thermic photosynthetic factor $\left(\mathrm{f}_{\mathrm{T}, \mathrm{FS}}(\mathrm{T})\right)$ which depends exclusively on temperature can range between 0 and 1, where higher valuesare favourable for algae growth. According to Figure 7at the beginning of the experimental study (first 5 days) the conditions were morefavourable for microalgae growth, and slightly worsened after that (Figure 7). Temperature values (shown in Figure 8 , from $9^{\circ} \mathrm{C}$ up to $18^{\circ} \mathrm{C}$ ), give values of the photosynthetic thermal factor oscillating between 0.38 and 0.8 . Meanwhile low temperature from day 6 to 9 (from $9^{\circ} \mathrm{C}$ up to $12^{\circ} \mathrm{C}$ ) decreased microalgae activity. This phenomenon can be observed by looking at the biomass growth rate (slope of the curve of Figure 3), which decreases slightly after day 5.

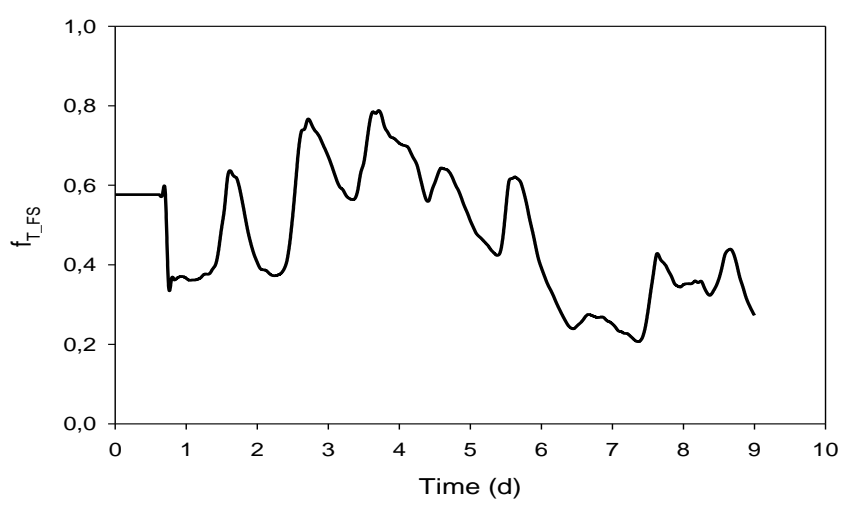




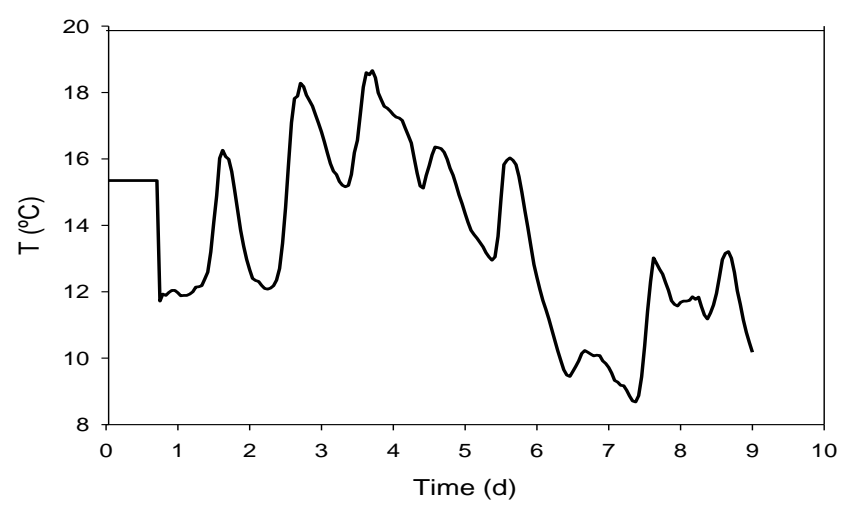

Figure 8.Temperature measurements $(T)$ over the 9 days of the experiment.

Table 4 presents the values of the parameters that werecalibrated to obtain the results of Figures 3 to 7.

Table 4.Values of calibrated parameters.

\begin{tabular}{|c|c|c|}
\hline Parameter & Description & Value \\
\hline$\mu_{A L G}$ & $\begin{array}{c}\text { Maximum specific growth rate of } \\
\text { microalgae }\end{array}$ & $1.5 \mathrm{~d}^{-1}$ \\
\hline $\mathrm{K}_{\mathrm{a}, \mathrm{O} 2}$ & Mass transfer coefficient foroxygen & $4 \mathrm{~d}^{-1}$ \\
\hline $\mathrm{K}_{\mathrm{a}, \mathrm{CO} 2}$ & $\begin{array}{c}\text { Mass transfer coefficient forcarbon } \\
\text { dioxide }\end{array}$ & $0.6 \mathrm{~d}^{-1}$ \\
\hline $\mathrm{K}_{\mathrm{a}, \mathrm{NH} 3}$ & Mass transfer coefficient for ammonia & $0.6 \mathrm{~d}^{-1}$ \\
\hline
\end{tabular}

\section{Discussion}

\subsection{Innovative features of the model}

The main innovation of the current model comes from consideringinorganic carbon as a limiting substrate for the growth of microalgae.Previous research on microalgae growth modelingfocused onproperly describingthe dependence of microalgae growthon light, while carbon limitation was not addressed(Wu and Merchuk, 2001; Franz et al., 2012). Thisapproachwas justified by the fact the growth of microalgae was studied in photobioreactors in which carbon dioxide was supplied throughinjection and thus carbonavailabilitywas always ensured (Bitog et al., 2011).However, microalgae grown in wastewater systems such as HRAP, in which no external carbon dioxide is supplied,are usually carbon limited (Buhr and Miller, 1983).Hence, in this case, it is essential to consider carbon limitation for a correct estimation of biomass production. In the scenario simulated in this work it was shown how the model was able to simulate the dynamics of the carbon species and in this case it was observed that they did not hinder algae growth.Carbon limitation was implemented in the model by introducing the correction factor $K_{C, A L G}$ in the equation describing the growth rate ofmicroalgae (processes $1 \mathrm{a}$ and $1 \mathrm{~b}$ in Table 1). 
On the other hand, excessively high concentrations of carbon dioxide can also be counter-productive and inhibit the growth of microalgae (Kurano and Miyachi, 2005).Although in our experimental setup the excess of carbon dioxide is released to the atmosphere and does not inhibit algae growth, this effect has to be taken into accountin closed reactors. To this end, the presented model also implements the inhibitory effect of high concentration of carbon dioxide through the parameter $I_{C O 2, A L G}(\mathrm{Silva}$ and Pirt, 1984)(processes 1a and $1 \mathrm{~b}$ in Table 1).

Temperature has also an effect on the chemical equilibrium of species, $\mathrm{pH}$ and gas solubility (Bouterfas et al., 2002). In the current scenario, when temperatures decreased, photosynthetic activity also decreased.It is translated into lower $\mathrm{pH}$ oscillations $( \pm 0.2)$ during the day/night cycle (Figure 4).

Photosynthetic

processes

(e.g.photoinhibition

and photolimitation)andphotorespiration phenomenawere lumped together into a single parameter calledthephotosynthetic factor $\eta_{P S}\left(I, S_{O 2}\right)$. Among others, the photosynthetic factor includes the influence of irradiance on microalgal growth.In fact, this parameter is considered the main limiting factor in microalgae systems (Larsdotter, 2006; Park and Craggs, 2011).

The dynamic model of photosynthesis and photoinhibition presented by Eilers and Peeters (1992) solvesthe system of differential equations 3 to 6 considering constant light intensity $(I)$. In the current work this approach was also adopted. To reproduce the daily variation of light intensity we assumethat photosynthetic processes are fast compared to the rate of change of irradiance; hence, the activated photosynthetic factor $\left(x_{2}\right)$ quickly reaches equilibrium withinstantaneous irradiance (Camacho-Rubio et al., 2002).This simplification was required to obtain the analytical solution ofthe system of differential equations (3-6).

The second term of theEquation (2) $f_{P R}\left(S_{O 2}\right)$ considers the effects of photorespiration on microalgae growth, a phenomenon so far never modelled in largescale algal cultures. Chisti (2007) imposed a maximum concentration of oxygen dissolved in water equal to four times the value of air saturation. This concentration can be considered equal to7.1904 $\mathrm{gO}_{2} / \mathrm{m}^{3}$ (Rubio and Fernández, 1999). To this restriction must be added the fact that photorespiration phenomenon starts suddenly at high concentration of dissolved oxygen, without significant impact to low concentrations.

Despite the scarceinformation availableon modelling photorespiration, a photorespiration factor $f_{P R}\left(S_{O 2}\right)$ has been proposed in the current work (Equation11), representing the effects of high oxygen concentration in the culture medium. To obtain this expression, the limiting function of the Monod equation was reversed(Figure 9a). Figure 9bdescribes a function that equalszero for negligible dissolved oxygen concentration and increases suddenly with a vertical asymptote when dissolved oxygen concentration reaches the limit saturation $\left(\tau S_{O 2}{ }^{S A T}\right)$. The parameter $K_{P R}$, based on the affinity constant of Monod switching functions, is responsible for the velocity at which the value of the function increases for increasing dissolved oxygen concentrations. The expression that describes the behaviour of photorespiration was obtained by subtracting a unit fromthe resulting function (Figure 9c). 

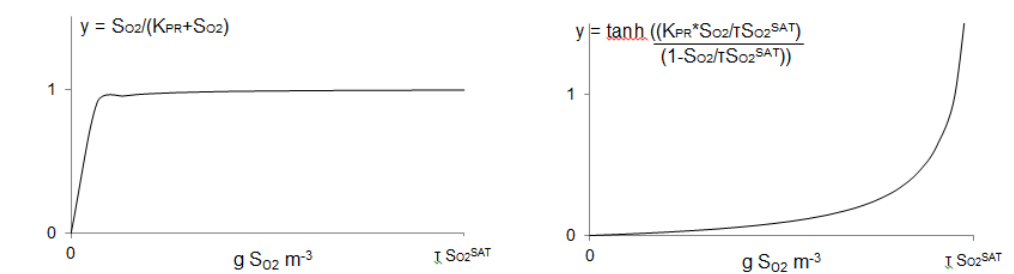

a)

b)

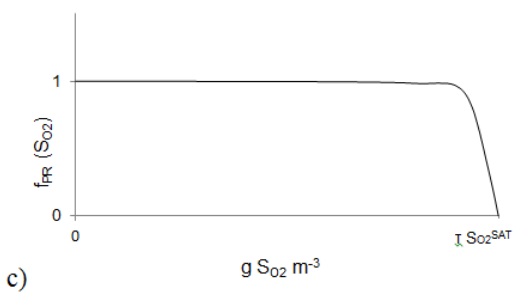

530

531

532

533

534

535

536

537

538

539

540

541

542

543

544

545

546

547

548

549

550

551

552

553

554

555

556

557

558

559

560

561

562

Figure 9.a)Monod-function for limiting substrate, b)hyperbolic tangent function, c)photorespiration factor.

In an open reactor oxygen is gradually transferred from the culture medium to the atmosphere, so the effect of photorespiration is negligible (as in our experiment). Photorespiration should be considered in closed photobioreactors.

The calibrated value of the maximum specific growth rate of microalgae $\left(\mu_{A L G}=1.5 \mathrm{~d}^{-}\right.$ $\left.{ }^{1}\right]$ ) fits well within literature ranges $\left[0.4-2 \mathrm{~d}^{-1}\right]$ (Reichert et al., 2001). Model results proved to be very sensitive to mass transfer coefficients to the atmosphere (Table 4), perhaps because all of these gases participate in a number of processes that either promote or inhibit microalgae growth depending on their concentrations.Indeed, intense photosynthesis can increase daytime dissolved oxygen levels in pond water up to more than $200 \%$ of the saturation concentration (García et al., 2000b, Molina-Grima et al., 2001). The exchange of dissolved oxygen between water andthe atmosphere occurs rapidly. Thus, to prevent high levels of dissolved oxygen in water, the coefficient of volatilization of oxygen $\left(K_{a}, O 2\right)$ was set so that theoxygen concentration in the culture mediumwould remain between 9 and $20 \mathrm{gO}_{2} / \mathrm{m}^{3}$. Carbon dioxide and nitrogen mass transfer were also calibrated.Although the values of these parameters can be found in the literature as a function of surface interface, in this work we had to calibrate them due to the OD domain used.

In accordance with daily variation of light intensity, simulated curvesshow a waveliketrendwhich indicates that model is able to reproduce the effects related to microalgae processes occurring during daytime and at night.

\subsection{Model limitationsand future developments}

In the current work a 0D domain was used to represent the microalgae culture in the mesocosm. This approach was adequate for the specific characteristics of our experimental system, since we assumed complete mixing conditions. However, HRAP and photobioreactors are characterized by more complex geometries and hydrodynamic regimes. In those cases both flow and transport equations will have to be coupled to the current model to obtain realistic results.

Light attenuation caused bypigments absorption and by the scattering andthe shading effect of the microalgae cells themselves(Sutherland et al., 2014)was not 
included in the current version of the model. However, numerous models (Quinn et al., 2011, Yuan et al. 2014) have been developed to estimate the gradient of light taking into account the aspects listed above.

Phosphorous species and theireffects on biological processes were not included in this model since this component is usually highly available in wastewaters and hence it does not cause any growth-limiting effects on microalgae(Larsdotter, 2006). However, predictions on the rate of removal of phosphorous species will require their inclusion in the model, which in fact can be easily done following the approach of the RWQM1.Once all the above mentioned ameliorations are included in the model, it will be capable to predict biomass production in HRAP and photobioreactors. A following step to fulfil our final objective will be to complete the model with the addition of bacterial processes and to validate the model with other experimental data.

\section{Conclusions}

In this paper a complex biokinetic model to simulate the dynamics of microalgae growth is presented. The biokinetic model is based on RWQM1 formulation and was implemented in COMSOL Multiphysics ${ }^{\mathrm{TM}}$ together with several other processes affecting microalgal biomass production in the widest possible range of microalgal cultures.

The most relevant features of the model is the inclusion an allowance for carbon limitation on the growth of microalgae, as well asthe dynamic model of photosynthesis and photolimitation and the description of the effect of photorespiration.

The model was calibrated by comparing simulated results to experimental data on microalgae growth in a mesocosm fed with synthetic culture medium (simulating a secondary effluent)for a period of 9 days. Although the results of the calibration indicate that the model was able to accurately reproduce microalgae growth, changes in nutrient concentrations and $\mathrm{pH}$, the model will require a subsequent verification with other real dataset. The results of this paper have to be considered as a conceptual exercise that could be manually adjusted to fit one single experiment. The value of the exercise is in fact in the development of the equations set and showing that a model based on the set can be run and calibrated to fit a real dataset.Furthermore, the growth of microalgae under naturallight/dark cycles and a dynamic model of photosynthesis(PSF)wereimplemented. The model wasable to represent the complex system of photosynthetic growth with simultaneous photoinhibition and photorespiration.

\section{References}

Acien , F., Fernández Sevilla, J.M., Molina Grima, E. 2013. Photobioreactors for the production of microalgae. Reviews in Environmental Science and Bio/Technology,Volume 12, Issue 2, pp 131-151. 
Béchet, Q., Shilton, A., Guieysse, B., 2013. Modelling the effects of light and temperature on algae growth: State of 1648-1663.

Bernard, O., Masci, P., Sciandra, A.A photobioreactor model in nitrogen limited conditions. In: Proceedings of the sixth conference on mathematical model- ling, Vienna, 2009.

Bitog, J.P., Lee, I.-B., Lee, C.-G., Kim, K.-S., Hwang, H.-S., Hong, S.-W., Seo, I.-H., Kwon, K.-S., Mostafa, E. 2011. Application of computational fluid dynamics for modelling and designing photobioreactors for microalgae production: A review. Computers and Electronics in Agriculture 76(2), 131-147.

Bonachela, J.A., Raghib, M., Levin, S.A. 2011.Dynamic model of flexibile phytoplankton nutrient uptake.Proc. Natl. Acad. Sci. U.S.A. 108, 20633-200638.

Bouterfas, R., Belkoura, M., Dauta, A., 2002.Light and temperature effects on the growth rate of three freshwater [2pt] algae isolated from a eutrophic lake. Hydrobiologia 489, 207-217.

Brennan, L., Owende, P. Biofuels from microalgae-A review of technologies for production, processing, and extractions of biofuels and co-products.Renewable and Sustainable Energy Reviews, 14, Issue 2, 2010, 557-577.

Buhr, H.O., Miller, S.B. 1983. A dynamic model of the high-rate algal bacterial wastewater treatment pond.Water Res 17:29-37.

Camacho Rubio F, García Camacho F, Fernández Sevilla JM, Chisti Y, Molina Grima E., 2003. A mechanistic model of photosynthesis in microalgae. Biotechnol Bioeng;81(4): 459-73. culture. Biotechnology and bioengineering $62,71-86$.

632 Chisti, Y., 2007. Biodiesel from microalgae. Biotechnology advances 25(3), 294-306.

Craggs, R.J., Heubeck, S., Lundquist, T.J., Benemann, J.R. (2011). Algae biofuel from wastewater treatment high rate algal ponds. Water Sci. Technol. 63(4), 660-665.

Craggs, R., 2005. Advanced integrated wastewater pond. In: Shilton, A. (Ed.), Pond Treatment Technology, IWA temperatura.Hydrobiologia 207, 221-226. Monochrysislutheri'. J. Mar. Biol. Ass. U.K. 48, 689-733. 

photosynthesis in phytoplankton. Ecological Modeling 42, 199-215.

Franz, A., Lehr, F., Posten, C., Schaub, G., 2012. Modeling microalgae cultivation productivities in different geographic locations - estimation method for idealized photobioreactors.Biotechnology Journal 7(4), 546-557.

648 García, J., Hernández-Mariné, M., Mujeriego, R., 1998. Tratamiento de aguas residuales urbanas mediante lagunas de 649 alta carga: evaluación experimental. Tratamiento de Aguas Residuales Urbanas 5, 35-50.

650 García, J., Hernández-Mariné, M., Mujeriego, R., 2008b. High rate algal pond operating strategies for urban 651 wastewater nitrogen removal. Journal of Applied Phycology 12, 331-339.

652 Guisasola, A., Petzet, S., Baeza, J., Carrera, J., Lafuente, J., 2007.Inorganic carbon limitations on nitrification : 653 Experimental assessment and modelling. Water research 41, 277-286.

654 Harris, G.P. 1978. Photosynthesis, productivity and growth: the physiological ecology of phytoplankton. Ergebnisse 655 der limnologie 10, 1-171.

656 Henze, M., Gujer, W., Mino, T., van Loosdrecht, M., 2000. Activated sludge models ASM1, ASM2, ASM2d and 657 ASM3. IWA Scientific and Technical Report No. 9, IWA Publishing, London, UK.

658 Huisman, J. Population dynamics of light-limited phytoplankton: microcosm experiments. Ecology 1999; $80202-10$.

659 Khorsandi, H., Alizadeh, R., Tosinejad, h., Porghaffar, H. 2014.Analysis of nitrogenous and algal oxygen demand in 660 effluent from a system of aerated lagoons followed by polishing pond.Water Science \& Technology $70.1-95$.

Kong, Q.X., Li, L., Martinez, B., Chen, P., Ruan, R., (2010). Culture of microalgae Chlamydomonasreinhardtii in 662 wastewater for biomass feedstock production.Applied biochem.andBiotechnol. 160, 9-18.

Kurano, N., Miyachi, S., 2005.Selection of microalgal growth model for describing specific growth rate-light response using extended information criterion.Journal of Bioscience and Bioengineering 100(4), 403-408.

Langergraber, G., Rousseau, D., García, J., Mena, J., 2009. CWM1: a general model to describe biokinetic processes in subsurface flow constructed wetlands. Water science and technology: a journal of the International Association on Water Pollution Research 59(9), 1687-97.

Larsdotter, K., 2006. Wastewater treatment with microalgae-a literature review.Vatten, 31-38.

673 Molina Grima, E., AciénFernández, G., Chisti, Y., 1999. Photobioreactors: light regime, mass transfer, and scaleup. 674 Journal of biotechnology 70, 231-247.

675 Molina Grima, E., Fernández, J., AciénFernández, G., Chisti, Y., 2001. Tubolar photobioreactor design for algae 676 cultures. Journal of biotechnology 92, 113-131.

677 Monod, J., 1949. The growth of bacterial cultures. Annual Reviews in Microbiology 3, 371-394.

678 Morris, M.D. 1991. Factorial Sampling Plans for Preliminary Computational Experiments.Technometrics, Vol. 33, 679 No. 2. pp. 161-174.

680 Mostert, E.S., Grobbelaar, J.H. 1987. The Influence of Nitrogen and Phosphorus on Algal Growth and Quality in 681 Outdoor Mass Algal Cultures.Biomass13 (1987) 219-233.

682 Novak, J.T., Brune, D.E. 1985. Inorganic carbon limited growth kinetics of some freshwater algae. Water Res. 19, 
Packer A, Li Y, Andersen T, Hu Q, Kuang Y, Sommerfeld M. Growth and neutral lipid synthesis in green

688 Park, J. B. K., Craggs, R. J. 2011. Algal production in wastewater treatment high rate algal ponds for potential biofuel 689 use. Water Sci. Technol., 63(10), 2403-2410.

690 Park, J.B.K., Craggs, R.J., Shilton, A.N., 2011a. Wastewater treatment high rate algal ponds for biofuel 691 production.Bioresource Technology, 102(1), 35-42.

692 Quinn, J., de Winter, L., Bradley, T., 2011. Microalgae bulk growth model with application to industrial scale 693 systems. Biosource Technology 102, 5083-5092.

694 Reichert, P., Borchardt, D., Henze, M., Rauch, W., Shanahan, P., Somlyódy, L., Vanrolleghem, P., 2001. River Water 695 Quality Model no. 1 (RWQM1): II. Biochemical process equations. Water science and technology: a journal of the 696 International Association on Water Pollution Research 43(5), 11-30.

Sah, L,. Rousseau, D., Hooijmans, C.M., Lens, P., 2011. 3D model for a secondary facultative pond. Ecological 698 Modelling 222(9), 1592-1603.

699 Sah, L., Rousseau, D., Hooijmans, C.M., 2012. Numerical Modelling of Waste Stabilization Ponds: Where Do We 700 Stand? Water, Air, \& Soil Pollution 223(6), 3155-3171.

701 Syrett, P.J. 1981. Nitrogen metabolism of microalgae.InPhysiological bases of phytoplankton ecology (T. Platt, ed.). 702 Canadian Bulletin of Fisheries and Aquatic Sciences 210:182-210.

703 Silva, H.J., Pirt, J. 1984.Carbon dioxide inhibition of photosynthetic growth of chlorella. Journal of General 704 Microbiology, 130, 2833-2838.

705 Sperling, M. V. 2007. Waste stabilization ponds. IWA Pubblishing, London, Uk.

706 Spolaore, P., Joannis-Cassan, C., Duran, E., Isambert, A. Commercial Applications of Microalgae.Journal of 707 bioscience and bioengineering 2006, 101, 87-96.

708 Stewart, W. D. P. (1974). Algal physiology and biochemistry, Blackwell Scientific Publications, Oxford, 989 pp.

709 Talbot, P., Gortares, M.P., Lencki, R.W., Noue de la J (1991). Absorption of $\mathrm{CO}_{2}$ in algal mass culture systems: A 710 different characterization approach. BiotechnolBioeng 37:834-842.

$711 \mathrm{Wu}, \mathrm{X} ., \mathrm{M}$ Merchuk, J., 2001. A model integrating fluid dynamics in photosynthesis and photoinhibition processes. 712 Chemical Engineering Science 56, 3527-3538.

713 Yuan, S., Zhou, X., Chen, R., Song, B., 2014. Study on modelling microalgae growth in nitrogen-limited culture 714 system for estimating biomass productivity. Renowable and Susteinable Energy Reviews 34 525-535.

715 Zonneveld, C., 1998. Light-limited microalgae growth: a comparison of modelling approaches. Ecological Modelling $716 \quad 11341-54$. 


\section{Supplementary Tables}

Supplementary Table 1.Values of biokinetic and physic parameters.

\begin{tabular}{|c|c|c|c|c|}
\hline Parameters & Description & Value & Unit & Source \\
\hline \multicolumn{5}{|c|}{ Microalgae processes } \\
\hline$\mu_{\mathrm{ALG}}$ & Maximum growth rate of microalgae & 1,6 & $d^{-1}$ & Calibrated \\
\hline $\mathrm{k}_{\mathrm{resp}, \mathrm{ALG}}$ & Endogenous respiration constant & 0,1 & $\mathrm{~d}^{-1}$ & (Reichert et al., 2001) \\
\hline $\mathrm{k}_{\text {death }, \mathrm{ALG}}$ & Inactivation constant & 0,1 & $d^{-1}$ & (Reichert et al., 2001) \\
\hline $\mathrm{K}_{\mathrm{C}, \mathrm{ALG}}$ & $\begin{array}{l}\text { Affinity constant of microalgae on carbon } \\
\text { species }\end{array}$ & 0,00432 & $\mathrm{gC} / \mathrm{m}^{3}$ & $\begin{array}{l}\text { (Novak and Brune, } \\
1985 \text { ) }\end{array}$ \\
\hline $\mathrm{I}_{\mathrm{CO} 2, \mathrm{ALG}}$ & $\mathrm{CO}_{2}$ inhibition constant of microalgae & 120 & $\mathrm{gC} / \mathrm{m}^{3}$ & (Silva and Pirt, 1984) \\
\hline $\mathrm{K}_{\mathrm{N}, \mathrm{ALG}}$ & $\begin{array}{l}\text { Affinity constant of microalgae on } \\
\text { nitrogen species }\end{array}$ & 0,1 & $\mathrm{gN} / \mathrm{m}^{3}$ & (Reichert et al., 2001) \\
\hline $\mathrm{K}_{02, \mathrm{ALG}}$ & $\begin{array}{l}\text { Affinity constant of microalgae on } \\
\text { dissolvedoxygen }\end{array}$ & 0,2 & $\mathrm{gO}_{2} / \mathrm{m}^{3}$ & (Reichert et al., 2001) \\
\hline \multicolumn{5}{|c|}{ Photorespiration factor } \\
\hline $\mathrm{K}_{\mathrm{PR}}$ & Inhibition constant of photorespiration & 0,01 & - & Assumption \\
\hline$\tau$ & Coefficient of excess dissolved oxygen & 4 & - & (Chisti, 2007) \\
\hline $\mathrm{S}_{02}^{\mathrm{SAT}}$ & $\begin{array}{l}\text { Saturation concentration of oxygen in the } \\
\text { air }\end{array}$ & 7,1904 & $\mathrm{gO}_{2} / \mathrm{m}^{3}$ & $\begin{array}{l}\text { (Camacho Rubio et al., } \\
\text { 1999) }\end{array}$ \\
\hline \multicolumn{5}{|c|}{ Photosynthetic thermal factor } \\
\hline $\mathrm{T}_{\mathrm{OPT}}$ & $\begin{array}{l}\text { Optimum temperature for microalgae } \\
\text { growth }\end{array}$ & 25 & ${ }^{\circ} \mathrm{C}$ & (Dauta et al., 1990) \\
\hline s & Normalized parameter & 13 & - & (Dauta et al., 1990) \\
\hline \multicolumn{5}{|l|}{ Light factor } \\
\hline$\alpha$ & Parameter activation & 0,001935 & $\left(\mu \mathrm{E} / \mathrm{m}^{2}\right)^{-1}$ & $\begin{array}{l}\text { (Wu andMerchuk, } \\
\text { 2001) }\end{array}$ \\
\hline$\beta$ & Parameter inhibition & $\begin{array}{l}5,7848 \\
* 10^{-7}\end{array}$ & $\left(\mu \mathrm{E} / \mathrm{m}^{2}\right)^{-1}$ & $\begin{array}{l}\text { (Wu and Merchuk, } \\
\text { 2001) }\end{array}$ \\
\hline$\gamma$ & Parameter production & 0,1460 & $s^{-1}$ & $\begin{array}{l}\text { (Wu and Merchuk, } \\
\text { 2001) }\end{array}$ \\
\hline$\delta$ & Parameter recovery & 0,0004796 & $\mathrm{~s}^{-1}$ & $\begin{array}{l}\text { (Wu and Merchuk, } \\
\text { 2001) }\end{array}$ \\
\hline \multicolumn{5}{|c|}{ Irradiance solar incident } \\
\hline $\mathrm{E}_{\mathrm{f}}$ & $\begin{array}{l}\text { Photosynthetic efficiency of solar } \\
\text { radiation }\end{array}$ & 1,74 & $\mu \mathrm{E} / \mathrm{J}$ & $\begin{array}{l}\text { (Molina Grima et al., } \\
\text { 1999) }\end{array}$ \\
\hline א & Index atmospheric clarity & 0,74 & - & $\begin{array}{l}\text { (Molina Grima et al., } \\
\text { 1999) }\end{array}$ \\
\hline$\zeta$ & Universal solar constant & 1353 & $\mathrm{~W} / \mathrm{m}^{2}$ & $\begin{array}{l}\text { (Molina Grima et al. } \\
\text { 1999) }\end{array}$ \\
\hline$\omega$ & Hour angle & Calculated & o & (Liu and Jordan, 1960) \\
\hline$\omega_{\mathrm{s}}$ & Sunset hour angle & Calculated & o & (Liu and Jordan, 1960) \\
\hline$\varphi$ & Latitude & Observed & o & - \\
\hline$\delta$ & Sun declination & Calculated & o & (Liu and Jordan, 1960) \\
\hline \multicolumn{5}{|c|}{ Transferof gasesto the atmosphere } \\
\hline $\mathrm{K}_{\mathrm{a}, \mathrm{O} 2}$ & Mass transfer coefficient for oxygen & 4 & $\mathrm{~d}^{-1}$ & Calibrated \\
\hline $\mathrm{K}_{\mathrm{a}, \mathrm{CO} 2}$ & $\begin{array}{l}\text { Mass transfer coefficient for dioxide } \\
\text { carbon }\end{array}$ & 0.7 & $\mathrm{~d}^{-1}$ & Calibrated \\
\hline $\mathrm{K}_{\mathrm{a}, \mathrm{NH} 3}$ & Mass transfer coefficient for ammonia & 0.7 & $d^{-1}$ & Calibrated \\
\hline
\end{tabular}

Supplementary Table 2.Values of chemical parameters.

\begin{tabular}{|c|c|}
\hline Parameters & Equations \\
\hline Chemical equilibriumCO ${ }_{2} \leftrightarrow \mathrm{HCO}_{3}^{-}$. & $\mathrm{K}_{\mathrm{eq}, 1}=10^{17,843-\frac{3404,71}{273,15+\mathrm{T}}-0,032786(273,15+\mathrm{T})}$ \\
\hline
\end{tabular}




\begin{tabular}{|c|c|c|c|c|c|}
\hline \multicolumn{2}{|c|}{ Chemical equilibrium $\mathrm{HCO}_{3}^{-} \leftrightarrow \mathrm{CO}_{3}^{2-}$} & \multicolumn{4}{|c|}{$\mathrm{K}_{\mathrm{eq}, 2}=10^{9,494-\frac{2902,39}{273,15+\mathrm{T}}-0.02379(273,15+\mathrm{T})}$} \\
\hline \multicolumn{2}{|c|}{ Chemical equilibriumNH$H_{4}^{+} \leftrightarrow \mathrm{NH}_{3}$} & \multicolumn{4}{|c|}{$\mathrm{K}_{\mathrm{eq}, 3}=10^{2,891-2727 /(273,15+\mathrm{T})}$} \\
\hline \multicolumn{2}{|c|}{ Chemical equilibriumH ${ }^{+} \leftrightarrow \mathrm{OH}^{-}$} & \multicolumn{4}{|c|}{$\mathrm{K}_{\mathrm{eq}, \mathrm{w}}=10^{-\frac{4470,99}{273,15+\mathrm{T}}+12,0875-0,01706(273,15+\mathrm{T})}$} \\
\hline \multicolumn{6}{|c|}{ Kinetics parameters } \\
\hline $\mathrm{k}_{\mathrm{eq}, 1}$ & \multicolumn{2}{|c|}{ Dissociation constant ofCO $\mathrm{C}_{2} \leftrightarrow \mathrm{HCO}_{3}^{-}$. } & 10000 & $d^{-1}$ & (Reichert et al., 2001) \\
\hline $\mathrm{k}_{\mathrm{eq}, 2}$ & \multicolumn{2}{|c|}{ Dissociation constant of $\mathrm{HCO}_{3}^{-} \leftrightarrow \mathrm{CO}_{3}^{2-}$} & 1000 & $\mathrm{~d}^{-1}$ & (Reichert et al., 2001) \\
\hline $\mathrm{k}_{\mathrm{eq}, 3}$ & \multicolumn{2}{|c|}{ Dissociation constant of $\mathrm{NH}_{4}^{+} \leftrightarrow \mathrm{NH}_{3}$} & 1000 & $d^{-1}$ & (Reichert et al., 2001) \\
\hline $\mathrm{k}_{\mathrm{eq}, \mathrm{w}}$ & \multicolumn{2}{|c|}{ Dissociation constant of $\mathrm{H}^{+} \leftrightarrow \mathrm{OH}^{-}$} & 1000 & $\mathrm{~g} * \mathrm{~m}^{-1} * \mathrm{~d}^{-1}$ & (Reichert et al., 2001) \\
\hline
\end{tabular}

Supplementary Table 3.Mathematical expressions of the stoichiometric coefficients of each process.

\begin{tabular}{|c|c|}
\hline Stoichiometric coefficient & Unit \\
\hline \multicolumn{2}{|l|}{ Microalgae growth on ammonia } \\
\hline $\mathrm{v}_{1,1 \mathrm{a}}=-\mathrm{i}_{\mathrm{N}, \mathrm{ALG}}$ & gN/gCOD \\
\hline $\mathrm{v}_{4,1 \mathrm{a}}=\frac{8 \mathrm{i}_{\mathrm{C}, \mathrm{ALG}}}{3}+8 \mathrm{i}_{\mathrm{H}, \mathrm{ALG}}-\mathrm{i}_{\mathrm{O}, \mathrm{ALG}}-\frac{12 \mathrm{i}_{\mathrm{N}, \mathrm{ALG}}}{7}$ & $\mathrm{gO}_{2} / \mathrm{gCOD}$ \\
\hline $\mathrm{v}_{5,1 \mathrm{a}}=-\mathrm{i}_{\mathrm{C}, \mathrm{ALG}}$ & $\mathrm{gC} / \mathrm{gCOD}$ \\
\hline $\mathrm{v}_{8,1 \mathrm{a}}=\frac{\mathrm{i}_{\mathrm{N}, \mathrm{ALG}}}{14}$ & $\mathrm{gH} / \mathrm{gCOD}$ \\
\hline $\mathrm{v}_{10,1 \mathrm{a}}=1$ & gCOD/gCOD \\
\hline \multicolumn{2}{|l|}{ Microalgae growth on nitrate } \\
\hline $\mathrm{v}_{3,1 \mathrm{~b}}=-\mathrm{i}_{\mathrm{N}, \mathrm{ALG}}$ & $\mathrm{gN} / \mathrm{gCOD}$ \\
\hline $\mathrm{v}_{4,1 \mathrm{~b}}=\frac{8 \mathrm{i}_{\mathrm{C}, \mathrm{ALG}}}{3}+8 \mathrm{i}_{\mathrm{H}, \mathrm{ALG}}-\mathrm{i}_{\mathrm{O}, \mathrm{ALG}}-\frac{20 \mathrm{i}_{\mathrm{N}, \mathrm{ALG}}}{7}$ & $\mathrm{gO}_{2} / \mathrm{gCOD}$ \\
\hline $\mathrm{v}_{5,1 \mathrm{~b}}=-\mathrm{i}_{\mathrm{C}, \mathrm{ALG}}$ & $\mathrm{gC} / \mathrm{gCOD}$ \\
\hline $\mathrm{v}_{8,1 \mathrm{~b}}=-\frac{\mathrm{i}_{\mathrm{N}, \mathrm{ALG}}}{14}$ & $\mathrm{gH} / \mathrm{gCOD}$ \\
\hline $\mathrm{v}_{10,1 \mathrm{~b}}=1$ & gCOD/gCOD \\
\hline \multicolumn{2}{|l|}{ Microalgae endogenous respiration } \\
\hline $\mathrm{v}_{1,2}=\mathrm{i}_{\mathrm{N}, \mathrm{ALG}}$ & $\mathrm{gN} / \mathrm{gCOD}$ \\
\hline $\mathrm{v}_{4,2}=\left(\mathrm{i}_{\mathrm{O}, \mathrm{ALG}}\right)-8\left(\mathrm{i}_{\mathrm{H}, \mathrm{ALG}}\right)-\frac{8}{3}\left(\mathrm{i}_{\mathrm{C}, \mathrm{ALG}}\right)+\frac{12}{7}\left(\mathrm{i}_{\mathrm{N}, \mathrm{ALG}}\right)$ & $\mathrm{gO}_{2} / \mathrm{gCOD}$ \\
\hline $\mathrm{v}_{5,2}=\mathrm{i}_{\mathrm{C}, \mathrm{ALG}}$ & $\mathrm{gC} / \mathrm{gCOD}$ \\
\hline $\mathrm{v}_{8,2}=-\frac{1}{14}\left(\mathrm{i}_{\mathrm{N}, \mathrm{ALG}}\right)$ & $\mathrm{gH} / \mathrm{gCOD}$ \\
\hline $\mathrm{v}_{10,2}=-1$ & $\mathrm{gCOD} / \mathrm{gCOD}$ \\
\hline \multicolumn{2}{|l|}{ Microalgae inactivation } \\
\hline $\mathrm{v}_{1,3}=\mathrm{i}_{\mathrm{N}, \mathrm{ALG}}$ & $\mathrm{gN} / \mathrm{gCOD}$ \\
\hline $\mathrm{v}_{4,3}=\left(\mathrm{i}_{\mathrm{O}, \mathrm{ALG}}\right)-8\left(\mathrm{i}_{\mathrm{H}, \mathrm{ALG}}\right)-\frac{8}{3}\left(\mathrm{i}_{\mathrm{C}, \mathrm{ALG}}\right)+\frac{12}{7}\left(\mathrm{i}_{\mathrm{N}, \mathrm{ALG}}\right)$ & $\mathrm{gO}_{2} / \mathrm{gCOD}$ \\
\hline $\mathrm{v}_{5,3}=\mathrm{i}_{\mathrm{C}, \mathrm{ALG}}$ & $\mathrm{gC} / \mathrm{gCOD}$ \\
\hline $\mathrm{v}_{8,3}=-\frac{1}{14}\left(\mathrm{i}_{\mathrm{N}, \mathrm{ALG}}\right)$ & $\mathrm{gH} / \mathrm{gCOD}$ \\
\hline $\mathrm{v}_{10,3}=-1$ & $\mathrm{gCOD} / \mathrm{gCOD}$ \\
\hline \multicolumn{2}{|l|}{ Chemical equilibria $\mathrm{CO}_{2} \leftrightarrow \mathrm{HCO}_{3}^{-}$} \\
\hline $\mathrm{v}_{5,4}=-1$ & $\mathrm{gC} / \mathrm{gC}$ \\
\hline $\mathrm{v}_{6,4}=1$ & $\mathrm{gC} / \mathrm{gC}$ \\
\hline $\mathrm{v}_{8,4}=1 / 12$ & $\mathrm{gH} / \mathrm{gC}$ \\
\hline \multicolumn{2}{|l|}{ Chemical equilibria $\mathrm{HCO}_{3}^{-} \leftrightarrow \mathrm{CO}_{3}^{2-}$} \\
\hline $\mathrm{v}_{6,5}=-1$ & $\mathrm{gC} / \mathrm{gC}$ \\
\hline $\mathrm{v}_{7,5}=1$ & $\mathrm{gC} / \mathrm{gC}$ \\
\hline$v_{8,5}=1 / 12$ & $\mathrm{gH} / \mathrm{gC}$ \\
\hline
\end{tabular}




\begin{tabular}{|l|c|}
\hline $\mathrm{v}_{1,6}=-1$ & $\mathrm{gN} / \mathrm{gN}$ \\
\hline $\mathrm{v}_{2,6}=1$ & $\mathrm{gN} / \mathrm{gN}$ \\
\hline $\mathrm{v}_{8,6}=1 / 14$ & $\mathrm{gH} / \mathrm{gN}$ \\
\hline Chemical equilibria $\mathbf{H}^{+} \leftrightarrow \mathbf{O H}^{-}$ & \\
\hline $\mathrm{v}_{8,7}=1$ & $\mathrm{gH} / \mathrm{gH}$ \\
\hline $\mathrm{v}_{9,7}=1$ & $\mathrm{gH} / \mathrm{gH}$ \\
\hline Oxygen transfer to the atmosphere & \multicolumn{2}{|}{-} \\
\hline $\mathrm{v}_{4,02}=1$ & \\
\hline Carbon dioxide transfer to the atmosphere & - \\
\hline $\mathrm{v}_{5, \mathrm{CO} 2}=1$ & \\
\hline Ammonia transfer to the atmosphere & - \\
\hline $\mathrm{v}_{2, \mathrm{NH} 3}=1$ & \multicolumn{2}{|l}{} \\
\hline
\end{tabular}

Supplmentary Table 4.Values of fraction of carbon, hydrogen, oxygen and nitrogen in microalgae biomass.

\begin{tabular}{|l|l|l|l|l|}
\hline Parameter & Description & Value & Unit & Source \\
\hline Fractions of microalgal biomass & Fraction of carbon in microalgae & 0,387 & gC/gCOD & (Reichert et al., 2001) \\
\hline $\mathrm{i}_{\mathrm{C}, \mathrm{ALG}}$ & Fraction of hydrogen in microalgae & 0,075 & gH/gCOD & (Reichert et al., 2001) \\
\hline $\mathrm{i}_{\mathrm{H}, \mathrm{ALG}}$ & Fraction of oxygen in microalgae & 0,538 & gO/gCOD & (Reichert et al., 2001) \\
\hline $\mathrm{i}_{\mathrm{O}, \mathrm{ALG}}$ & Fraction of nitrogen in microalgae & 0,065 & gN/gCOD & (Reichert et al., 2001) \\
\hline $\mathrm{i}_{\mathrm{N}, \mathrm{ALG}}$ &
\end{tabular}

